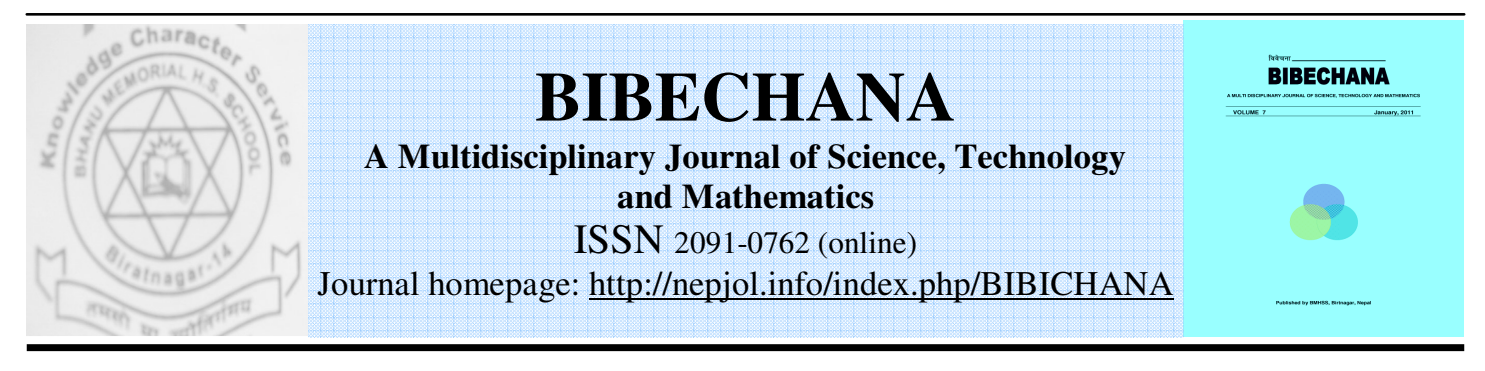

\title{
Role of reductant for generation of solar energy in photogalvanic cell
}

\author{
Mahesh Chandraa*, R.C. Meena $^{\mathrm{b}}$ \\ ${ }^{a}$ Department of Chemistry,Deshbandhu College,New Dehli-110019 \\ ${ }^{\mathrm{b}}$ Department of Chemistry, Jai Narain Vyas University, Jodhpur (Rajasthan)-342 005 \\ E-mail: rcmeena007@rediffmail.com \\ Article history: Received 15 October 2010;Revised 29 October 2010; Accepted 1 November 2010
}

\begin{abstract}
The Photo voltages and photocurrents in photo galvanic cell containing a dye Rose Bengal and Oxalic Acid as reducing agent have been determined. The photo-outputs with Oxalic Acid are higher than Rose Bengal and Mannitol system. The efficiency of the Rose Bengal -Oxalic Acid photo galvanic cell has been estimated to be $0.981 \%$.The photo potentials and photocurrent garneted, conversion efficiency, power of the cell and cell performance of the photo galvanic cells were determined. The effects of different parameters on electrical output of the cell were observed .A mechanism has also been proposed for the generation of the photocurrent in photo galvanic cell.
\end{abstract}

Keywords: Photo galvanic cell; Photopotential; Rose Bengal; Oxalic acid,; Mannitol; Power point

\section{Introduction}

Today, global warming and the rapid decrease in energy resources caused by the largescale consumption of fossil fuels have become serious. Accordingly renewable energy resources are attracting a great deal of attention, and solar energy is one of the most promising future energy resources. The photo effects in electrochemical systems were first reported by Becquerel $[1,2]$ in his investigation on the solar illumination of metal electrodes long back. Surash and Hercules [3] proved that only negative photo potential should be obtained with carbonyl compounds. Alonso et al. [4] reported the use of electrodeposited CdSe0-5 Te0-5 electrode for solar energy conversion. Jana and Bhowmik [5] reported enhancement in the power output of a solar cell consisting of mixed dyes. Hara et al. [6] investigated design of new coumarin dyes having thiophene moieties for highly efficient organic dye-sensitized solar cells. Ameta et al. [7] reported use of toluidine blue nitroloacetic acid (TB-NTA) system in photo galvanic cell for solar energy conversion. They also reported the use of micelles in photo galvanic cell for solar energy conversion and storage in Azur A-Glucose system [8], Bromophenol-EDTA system [9] and Fluoroscein-EDTA system [10]. Bohrmann-Linde and Tausch [11] reported photo galvanic cells

\footnotetext{
* Corresponding author: Dr. Mahesh Chandra, Asstt. Prof., Department of Chemistry, Deshbandhu College, New Dehli-110019 [INDIA]. Mob.No. +91-09968347362, E-mail: drmahesh100@gmail.com
} 
for classroom investigation, and Monat and McCusker [12] reported femto-second excited state dynamics of an iron (II) polypyridyl solar cell. Schwarzhurg and Willig [13] explored the origin of photo voltage and photocurrent in nanoporous, dye-sensitized, photo electrochemical solar cell. The sensitization of nanoporous films of $\mathrm{TiO} 2$ with santaline (red sandal wood pigment) and the construction of a dye-sensitized solid-state photovoltaic cell was attempted by Tennakone and Kumara [14]. Yadav et al. [15] reported use of Bismarck Brown-Ascorbic Acid (BB-AA) system in photogalvanic cell for solar energy conversion. Photo galvanic cells containing reductants and photo sensitizers [16-33] were reported.

The research in the field of photogalvanic cells is still in its infancy with respect to its viability and practical applicability and, therefore, requires thorough exploration to increase the conversion efficiency and storage capacity by selecting a suitable redox couple and photo sensitizers. A detailed survey of literature reveals that no attention has been paid to electrochemical behaviour of Rose Bengal-Oxalic Acid and Mannitol has also been investigated at platinum electrode in presence of these reducing agents; therefore, the present work has been undertaken

\section{Experimental}

Rose Bengal (LOBA), Oxalic Acid (LOBA), Mannitol (LOBA) and sodium hydroxide (s.d. fine) were used without further purification in present work. All the solutions were prepared in doubly distilled water and were kept in amber colored containers to protect them from sunlight. The whole system was set up systematically for photo galvanic studies consists of two thin foilles of electrochemically treated platinum as electrodes and saturated calomel electrodes as a reference electrode the distance between the illuminated and dark electrode is approx $45 \mathrm{~mm}$.An ordinary tungsten lamp of 200 as light source. Water filter was used to cut off IR radiations. The photopotetial was obtained as the difference between the initial potential of the system in dark and the equilibrium potential the system attains under constant illumination. The potential was first measured in dark and the change in potential on illumination was measured as a function of time. All the solution was bubbled with prepurified nitrogen gas for nearly twenty minutes to remove dissolved oxygen. Solutions of dye, reductant and sodium hydroxide were taken in an $\mathrm{H}-$ tube glass tube. A platinum electrode $\left(1.0 \times 1.0 \mathrm{~cm}^{2}\right)$ was immersed into one arm of H-tube and a saturated calomel electrode (SCE) was kept in the other. The whole system was first placed in dark till a stable potential was obtained, then the arm containing the SCE was kept in the dark and the platinum electrode was exposed to a $200 \mathrm{~W}$ tungsten lamp. A water-filter was used to cut off infrared radiations. The photochemical bleaching of Rose Bengal was studied potentiometrically. A digital $\mathrm{pH}$ meter (Systronices) and a micro-ammeter (OSAW, India) were used to measure the potential and current generated by the system, respectively. The i-V characteristics of the cells were studied using an external load $(\log 470 \mathrm{k})$ in the circuit. The effect of variation of different parameters has also been observed. The rate of change in potential after removing the source of illumination was $1.20 \mathrm{~min}$ in Rose Bengal-Oxalic Acid; therefore, the system may be used in photo galvanic cell more successfully than the Rose Bengal and Mannitol system.

\section{Results and Discussion}

\subsection{Rose Bengal-Oxalic Acid Systems}

The photo potential of Rose Bengal-Oxalic Acid system was measured at different $\mathrm{pH}$ values and maximum photo potential was found at $\mathrm{pH} 12.6$ All the subsequent measurements were made at this $\mathrm{pH}$ value. The variation of photo potential with time for this system is shown in Figure 1. As can he has seen from the figure, the photo potential increases upon illumination to a 
value of $1239.0 \mathrm{mV}$ in about $260.0 \mathrm{~min}$. and remains constant on further illumination. When the light is switched-off, the system regains its original potential immediately, thereby showing that the system is perfectly reversible.

\subsection{Rose Bengal-Mannitol Systems}

The photo potential of Rose Bengal-Mannitol system was measured at different $\mathrm{pH}$ values and maximum photo potential was found at $\mathrm{pH}$ 11.0. All the subsequent measurements were made at this $\mathrm{pH}$ value. The variation of photo potential with time for this system is shown in Figure 2. As can he seen from the figure, the photo potential increases upon illumination to a value of $1080.0 \mathrm{mV}$ in about $315.0 \mathrm{~min}$. and remains constant on further illumination. When the light is switched-off, the system regains its original potential immediately, thereby showing that the system is perfectly reversible. We have also examined the photocurrent of Rose Bengal in presence of Mannitol. The observed photo potentials and currents are comparable less than that of Rose Bengal-Oxalic Acid system (Table 1). The Photoionduced short circuit currents of Rose Bengal-Oxalic Acid and Rose Bengal-Mannitol in photo galvanic cells are shown in fig.3. On illumination maximum photocurrents are obtained 190.0 in $315.0 \mathrm{~min}$ in Rose Bengal - Oxalic Acid System and 180.0 in $260.0 \mathrm{~min}$ in Rose Bengal-Mannitol system. The Rose BengalMannitol system takes much smaller time than that of Rose Bengal-Oxalic Acid system. The trend in short circuit photocurrents of Rose Bengal-Oxalic Acid is much better than Rose BengalMannitol system (Table 1).

\subsection{Power conversion efficiency of Photo galvanic cell}

One of the important characteristics of any electrochemical cell is its power conversion efficiency. The i-V characteristics of Rose Bengal- Oxalic Acid and Rose Bengal-Mannitol photo galvanic cell have been investigated to estimate the power conversion efficiency of the cell. The typical i-V curve shown in Figure 3. The possible power output from the cell can be obtained from the rectangle of maximum area which can be drawn under $\mathrm{i}-\mathrm{V}$ curve.

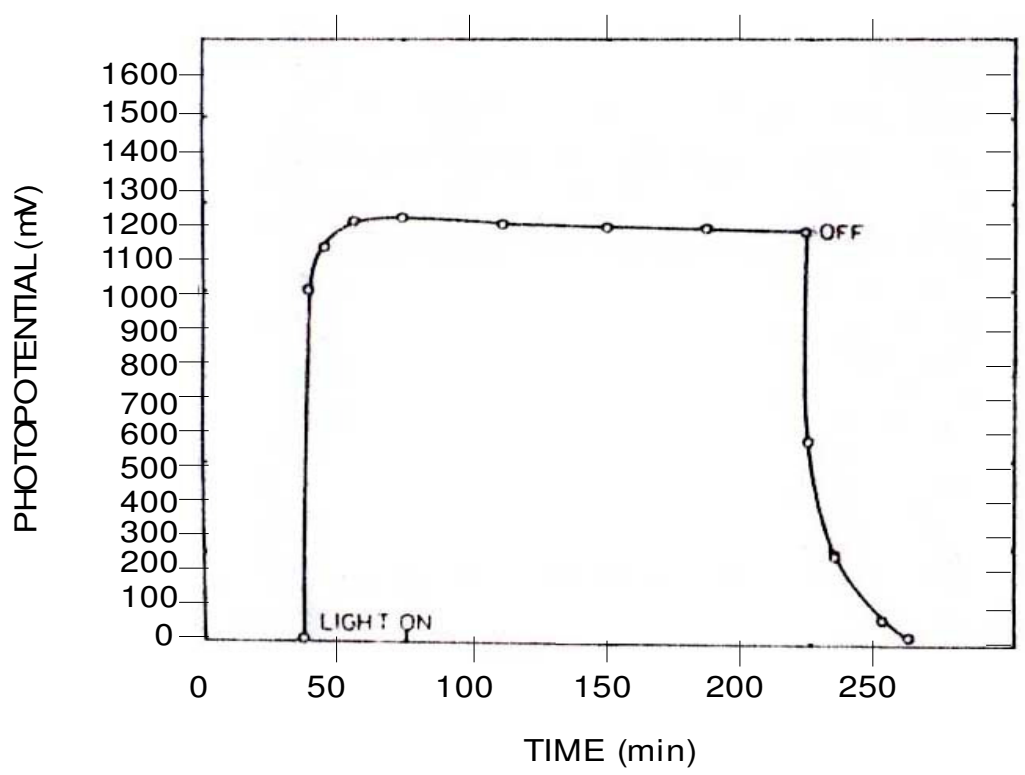

Figure 1: Variation of photo potential with time in Rose Bengal-Oxalic Acid in Photo galvanic cell 
The power point (a point on the curve where the product of potential and current was maximum) in $\mathrm{i}-\mathrm{V}$ curves were determined and their fill factors were also calculated. These data are summarized in table 2. The efficiency of the Rose Bengal-Oxalic Acid photo galvanic cell has been calculated to be 0.981 percent, comparable to that of and Rose Bengal-Mannitol photo galvanic cell has been calculated to be 0.744 percent

Table 1

\begin{tabular}{|c|c|c|}
\hline Observations & $\begin{array}{c}\text { Rose Bengal- Oxalic Acid } \\
\text { system }\end{array}$ & $\begin{array}{c}\text { Rose } \\
\text { Bengal-Mannitol } \\
\text { System }\end{array}$ \\
\hline Open Circuit voltage $\left(\mathrm{V}_{\mathrm{oc}}\right)$ & $1239.0 \mathrm{mV}$ & $1080.0 \mathrm{mV}$ \\
\hline Photo potential (V) & $1137.0 \mathrm{mV}$ & $968.0 \mathrm{mV}$ \\
\hline Equilibrium Photocurrent $\left(\mathrm{i}_{\mathrm{eq}}\right)$ & $160.0 \mu \mathrm{A}$ & $160.0 \mu \mathrm{A}$ \\
\hline Maximum Photocurrent $\left(i_{\max }\right)$ & $190.0 \mu \mathrm{A}$ & $180.0 \mu \mathrm{A}$ \\
\hline Short circuit current $\left(i_{\mathrm{sc}}\right)$ & $175.0 \mu \mathrm{A}$ & $160.0 \mu \mathrm{A}$ \\
\hline Current at power point $\left(\mathrm{i}_{\mathrm{pp}}\right)$ & $110.0 \mu \mathrm{A}$ & $100.0 \mu \mathrm{A}$ \\
\hline Potential at power point $\left(\mathrm{V}_{\mathrm{pp}}\right)$ & $1022.0 \mu \mathrm{A}$ & $704.0 \mu \mathrm{A}$ \\
\hline Power at power point & $64.0 \mu \mathrm{A} / \mathrm{min}$ & $62.8 \mu \mathrm{A} / \mathrm{min}$ \\
\hline Rate of Generation & $56.8 \mu \mathrm{A} / \mathrm{min}$ & $56.0 \mu \mathrm{A} / \mathrm{min}$ \\
\hline Conversion Efficiency & $0.981 \%$ & $0.744 \%$ \\
\hline Charging Time & $180.0 \mathrm{~min}$ & $260.0 \mathrm{~min}$ \\
\hline $\mathrm{t} 1 / 2$ & $90.0 \mathrm{~min}$ & $60.0 \mathrm{~min}$ \\
\hline Fill factor $(\mathrm{n})$ & 0.51 & 0.44 \\
\hline
\end{tabular}




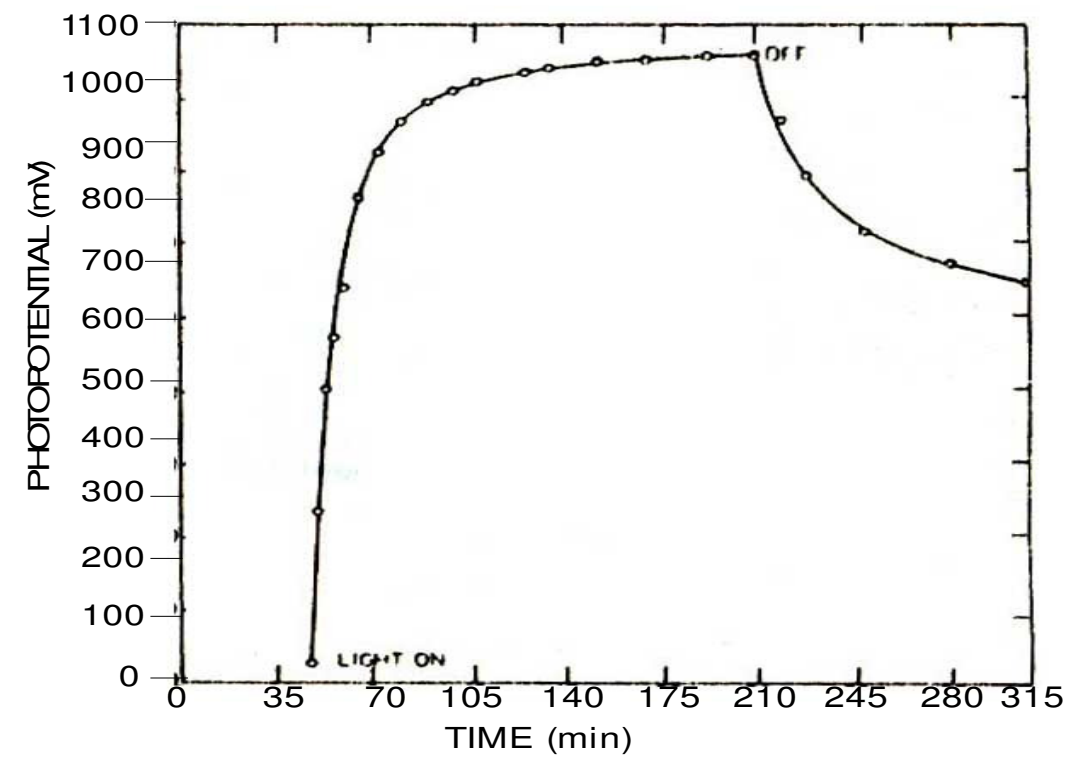

Figure 2: Variation of photo potential with time in Rose Bengal-Mannitol in Photo galvanic cell

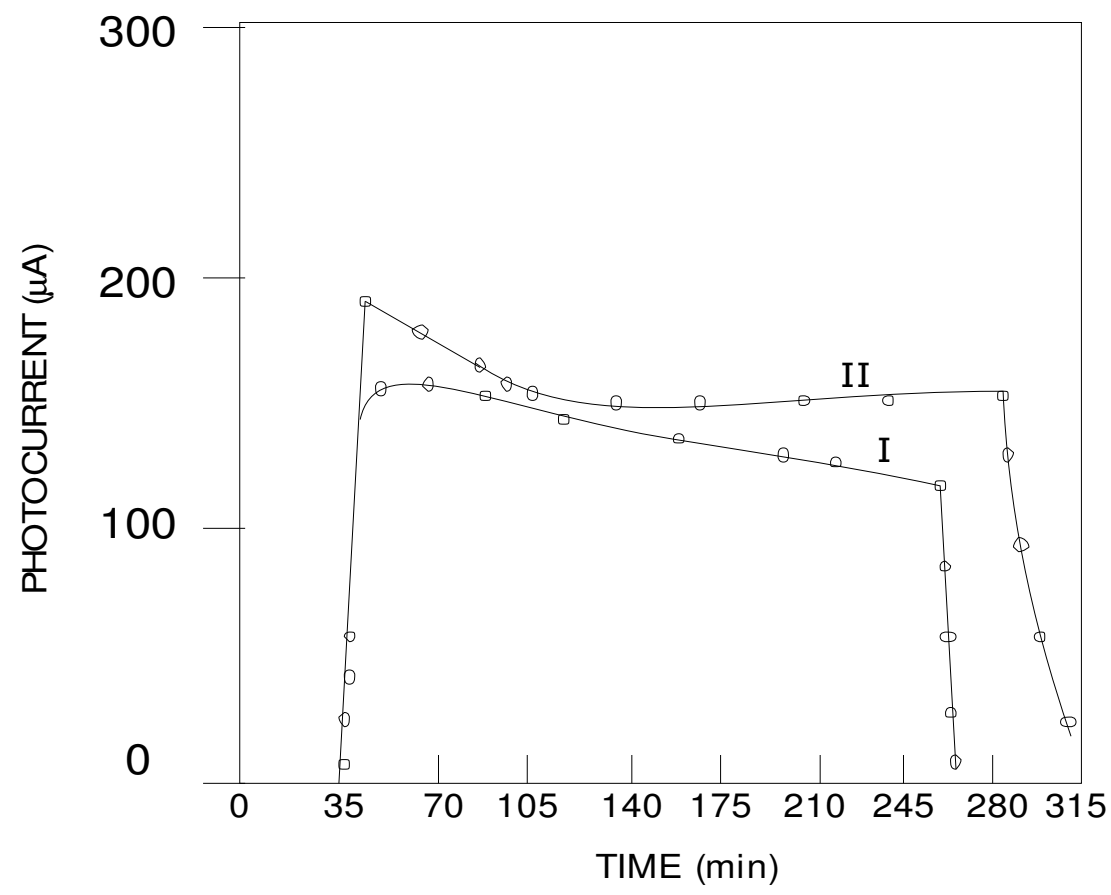

Figure 3: Variation of photo potential with time in (I) Rose Bengal-Oxalic Acid and (II) Rose Bengal- Mannitol Photo galvanic cell 
Table 2: i-V Characteristics of the Photogalvanic Cells

\begin{tabular}{|l|c|c|c|c|c|}
\hline \multicolumn{1}{|c|}{ Systems } & $\begin{array}{c}\mathrm{V}_{\mathrm{oc}} \\
(\mathrm{mV})\end{array}$ & $\begin{array}{c}\mathrm{i}_{\mathrm{sc}} \\
(\mu \mathrm{A})\end{array}$ & $\begin{array}{c}\mathrm{V}_{\mathrm{pp}} \\
(\mathrm{mV})\end{array}$ & $\begin{array}{c}\mathrm{i}_{\mathrm{pp}} \\
(\mu \mathrm{A})\end{array}$ & $\mathrm{n}$ \\
\hline Rose Bengal-Oxalic Acid & 1239 & 175.0 & 1022.0 & 110.0 & 0.51 \\
\hline Rose Bengal-Mannitol & 1080 & 160.0 & 704.0 & 100.0 & 0.44 \\
\hline
\end{tabular}

The conversion efficiency and sunlight conversion data for these two systems are reported in table 3 .

Table 3 : Conversion Efficiency and Sunlight Conversion Data

\begin{tabular}{|c|c|c|c|c|}
\hline & Fill & Conversion & \multicolumn{2}{|c|}{ Sunlight Conversion Data } \\
\cline { 4 - 5 } & Factor & $\begin{array}{c}\text { Efficiency } \\
(\mathbf{\%})\end{array}$ & $\begin{array}{c}\text { Photo potential } \\
(\mathbf{m V})\end{array}$ & $\begin{array}{c}\text { Photocurrent } \\
(\mu \mathbf{A})\end{array}$ \\
\hline $\begin{array}{c}\text { Rose Bengal-Oxalic } \\
\text { Acid }\end{array}$ & 0.51 & 0.98 & 1239 & 190 \\
\hline $\begin{array}{c}\text { Rose Bengal- } \\
\text { Mannitol }\end{array}$ & 0.44 & 0.74 & 1080 & 180 \\
\hline
\end{tabular}

On the basis of these observations, the highest conversion efficiency was found in Rose BengalOxalic Acid system.

\subsubsection{Performance of the Cell}

The results obtained have been given in the tables 4 . All the two systems were studied by applying the desired external load to have the potential and current corresponding to power point. The time $t 1 / 2$ was determined after removing the source of light. It is the time taken in reaching half the value of power. The performance of cells was studied and comparative values are summarized in the table 4 .

Table 4: Performance of the Photogalvanic Cells in Dark

\begin{tabular}{|c|c|c|}
\hline System & Power $(\mu \mathbf{W})$ & $\mathbf{t}_{\mathbf{1} / \mathbf{2}}(\mathbf{m i n})$ \\
\hline Rose Bengal-Oxalic Acid & 64.0 & 90.0 \\
\hline Rose Bengal-Mannitol & 62.8 & 60.0 \\
\hline
\end{tabular}

On the basis of the observed data, the Rose Bengal-Oxalic Acid is the most efficient from power point of view (Electrochemical Studies of Photo sensitizers). 


\subsubsection{Mechanism}

On the basis of these observations, a mechanism is suggested for the generation of photocurrent in the photo galvanic cell as:

Illuminated Chamber

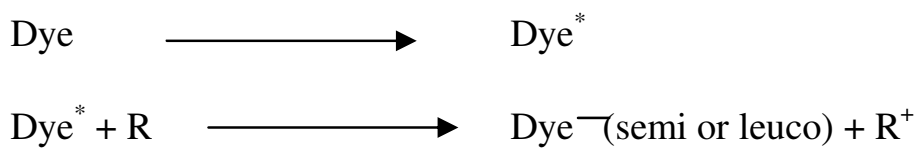

\section{At Platinum Electrode}

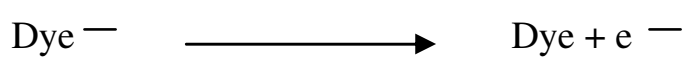

\section{Dark Chamber}

$$
\begin{aligned}
& \text { Dye }+\mathrm{e}^{-} \longrightarrow \text { Dye }^{-} \text {(semi or leuco) } \\
& \text { Dye }-+\mathrm{R}^{+} \longrightarrow \text { Dye }+\mathrm{R}
\end{aligned}
$$

Where Dye, Dye*, Dye , R and R+ are the excited form of dye, semi or leuco dye, reductant and oxidized form of the reductant, respectively.

\section{Conclusion}

Photo galvanic cells are low cost due to the use of a dye, which are cheap and used in minute quantities reductant like Ascorbic acid, is also not that very expensive. So overall working with a photo galvanic cell has lot of scope for its development.

On the basis of observation in the whole study it is concluded that photo galvanic cells are better option for solar energy conversion and storage. Also this system with better electrical output good performance and storage capacity may be used in near future. According to observed photo galvanic effect in all these two systems, Rose Bengal-Oxalic Acid system was the most efficient in all the ways.

\section{Acknowledgement}

The Authors are grateful to Principal, Deshbandhu College, Kalkaji New Delhi for providing the necessary laboratory facilities.

\section{References}

[1] E.Becquerel, C.R. Acad. Sci. Paris., 9 (1839a) 145.

[2] E.Becquerel, C. R. Acad. Sci. Paris, 9 (1839a) 561.

[3] J.J.Surash , D.M.Hercules, J. Phys. Chem., 66 (1962)1602.

[4] A.V.Alanso, M. Belay, P.Chartier, V.Ern, Rev. Phys. Appl.,16 (1981)5.

[5] A.K.Jana , B.B.Bhowmik, J. Photochem. Photobiol., 122A, 53(1999) 53.

[6] K.Hara ,M.Kurashige,Y.Dan-oh,C.Kasada, A .Shinpo ,S. Suga , K.Sayama , H. Arakawa , New J. Chem., 27 (2003) 783. 
[7] S .C.Ameta, R. Ameta, S. Seth, T.D.Dubey, Afinidad, XLV (1988)264.

[8] S .C.Ameta, S. Khamesare, R. Ameta , M. Bala , Int. J. Energy Res., 14 (1999)163.

[9] S.C. Ameta, P.B. Punjabi, J.Vardia, S .Madhwani, S.Chaudhary,J.Power Sources, 159 (2006) 747.

[10] S.Madhwani, R. Ameta, J.Vardia, P.B.Punjabi, V.K. Sharma, Energy Sources, 29 (2007 )721.

[11] C .Bohrmann-Linde, M.W. Tausch, J. Chem. Educ., 80 (2003) 1471.

[12] J.E. Monat, J. K. McCusker, J. Amer. Chem. Soc., 122 (2000) 4092.

[13] K.Schwarzburg, F. Willig, J. Phys. Chem., 103B (1999) 5743.

[14] K.Tennakone, GRR.A.Kumara, J. Photochem. Photobiol, 117A (1998)137.

[15] Sushil Yadav, R. D. Yadav, Gautam Singh, Int. J. Chem. Sci., 6(4) (2008) 1960.

[16] R.C. Meena , R.S.Sindal, Int. J. Chem. Sci., 2(3) (2004) 321.

[17] Suresh C. Ameta, Sadhana Khamesra, Anil K. Chittoro , K.M.Gangotri.,.Int.J.Energy Res., 13 (1989) 643.

[18] K.M.Gongotri, R.C. Meena , Rajni Meena., J. Photochem and photobiol. A: Chem; 123 (1999) 93.

[19] K.M.Gangotri , Chhagan Lal., Int. J. Energy Res., 24 (2000)365.

[20] A.C. Fisher, L.M. Peter, E.A. Ponomareve, A.B. Walker, K.G.U. Wijayantha., J. Phys. Chem. B, 104(5) (2000) 949.

[21] Zhi-Ying Zhang, Chun-yanliu., J. Photochem. and Photobio. A: Chemistry, 130 (2000)139.

[22] Michael Gratzel, J. Photochem.and Photobiol. A: Chemistry, 164 (2004) 3.

[23] A.Hameed, M.A.Gondal, J. Molecular Catalysis A: Chemical, 219 (2004) 109.

[24] Coralie Houarner-Rassin, Errol Blart, Pierrick Buvat, Fabriceodobel, J. Photochem.and Photobiol A: Chemistry, 186 (2007)135.

[25] J.Bandara, U.W. Pradeep, R.G.S.J. Bandara., Solar Cells , 170 (2005) 273.

[26] R.S.Sindal, R.K.Gunsaria,Mahesh Chandra, R.C. Meena, The Arabian Journal for science and Engineering, 31(2A) (2006)177.

[27] Minna Toivola, Lauripeltokorpi, Janne Halme, Peter Lund, Solar energy materials and solar Cells, 91 (2007) 1733.

[28] Mural Kenisarin, Khamid Mahkamov, Renewable and Sustainable energy reviews, 11 (2007) 1913.

[29] R.S.Sindal,Mahesh Chandra , R.C.Meena , J.Ind.Council Chem ,25(2) (2008)131.

[30] Sonal Sirvi, Vijay Kumar Meena, R. C.Meena, J. Indian Chem.Soc., 85 (2008) 825.

[31] R.C.Meena, J.Indian Chem. Soc., 85 (2008) 280.

[32] R.S.Sindal, M. Chandra, V.Kumar, R.C. Meena, Energy Sources, 31(16) (2009) 1.

[33] Manju Kumari, Ram Babu Pachwarya, R.C. Meena, Int J. Energy Sources, 31(11) (2009) 1. 